\title{
TRANSFORMASI PERILAKU KEAGAMAAN DI ERA MEDIA BARU 4.0
}

\author{
Nurhasanah \\ STAI Ar-Ridho Bagansiapiapi, Rokan Hilir \\ E-mail: nurhasanahnina270292@gmail.com
}

\begin{abstract}
Abstrak
Penelitian ini bertujuan untuk mengetahui bagaimana transformasi perilaku keagamaan di era media baru 4.0 dan apa upaya dalam mengatasi transformasi perilaku keagamaan dalam penguatan moderasi beragama di era media baru 4.0. Metode penelitian menggunakan studi literatur dengan mengumpulkan data dari dokumentasi menggunakan metode deskriptif-analisis. jenis metode pengumpulan data kepustakaan (Library Research). Metode yang penulis pakai yaitu kajian dengan mempelajari dan menelusuri literatur yang berkenaan dengan duduk perkara yang di teliti baik berupa buku-buku, artikel-artikel, website dan tulisan lain yang mengandung gosip dan data-data yang berkaitan menggunakan judul. Hasil penelitian menunjukkan bahwa transformasi sikap keagamaan sedang mengalami gejolak arus revolusi industri. Perubahan cara pandang menciptakan atau mengelola industri ini pula juga berdampak pada cara orang memahami kepercayaan, mengekspresikan, serta mengkomunikasikan pada orang lain. Masyarakat yang merespon kenyataan-fenomena sikap yang disuguhkan media di era 4.0 ini, memberikan perubahan bersikap dan berperilaku dalam penggunaannya sebagai akibatnya nilai agama mulai mengalami perubahan (transpormasi). Upaya dilakukan menjadi penguatan pendidikan keagamaan dikalangan warga dalam menghadapi perubahan-perubahan sikap masyarakat di era 4.0 ini. Islam memikirkan upaya yang tepat dalam menghadapi perubahan-perubahan perilaku tersebut. pada korelasi ini pendidikan kepercayaan berfungsi menjadi usaha membina insan secara religi serta kaffah yang mampu menyesuaikan diri pada menghadapi Era 4.0, dimana indivisu dituntut kreatif menyikapi media sebagai alat komunikasi di era industri yang serba cepat, sempurna, efektif serta efisien.
\end{abstract}

Kata Kunci: Transformasi, Perilaku Keagamaan, Era Media Baru.

\begin{abstract}
This study aims to find out how the transformation of religious behavior in the new media era 4.0 and what efforts are made to overcome the transformation of religious behavior in strengthening religious moderation in the new media era 4.0. The research method uses literature study by collecting data from documentation using descriptive-analytical method. types of library data collection methods (Library Research). The method that the author uses is a study by studying and browsing the literature relating to the subject being studied in the form of books, articles, websites and other writings containing information and related data using titles. The results of the study indicate that the transformation of religious attitudes is experiencing turbulence in the flow of the industrial revolution. This changing
\end{abstract}


perspective on creating or managing this industry also has an impact on the way people understand beliefs, express, and communicate to others. People who respond to the behavioral phenomena presented by the media in this 4.0 era, provide changes in attitude and behavior in their use as a result of which religious values begin to change (transformation). Efforts were made to strengthen religious education among citizens in the face of changes in people's attitudes in this 4.0 era. Islam thinks of appropriate efforts in dealing with these behavioral changes. In this correlation, trust education functions as an effort to foster religious and spiritual people who are able to adapt to face Era 4.0.

Keywords: Transformation, Religious Behavior, New Media Era.

\section{PENDAHULUAN}

Perubahan umumnya akan terjadi dalam kehidupan masyarakat tradisional maupun modern. Dinamika perubahan tersebut berdampak pada segala gerak kehidupan insan, termasuk pada sektor pendidikan yang digambarkan melalui sikap manusia pada beragama. Transformasi sikap keagamaan ketika ini pada Indonesia sedang mengalami gejolak arus revolusi industri tadi. sikap-sikap yang muncul antara lain kecanduan gadget, cyber bullying, atau bahkan turunnya moral atau akhlak. sehingga sudah sepatutnya penguatan pendidikan keagamaan dikalangan masyarakat Islam memikirkan upaya yang sempurna dalam menghadapi perubahan-perubahan perilaku tadi pada era media baru 4.0. ${ }^{1}$

Kepercayaan dalam hal ini mempunyai posisi yang sangat penting dalam kehidupan warga memakai aneka berbagai macam realitas dan liputan- liputan sosial yang ada di dalamnya. Bersumber pada fenomena yang terjalin, riset para pakar sosiologi melaporkan kalau agama maksudnya sesuatu pemikiran hidup yang harus diterapkan dalam kehidupan individual maupun kelompok. Keduanya mempunyai korelasi silih mensugesti serta silih tergantung memakai seluruh aspek yang turut membuat struktur sosial pada warga manapun. Islam mengarahkan untuk pemeluknya buat tetap membentuk pergantian yang positif di bermacam aspek kehidupan. Terpaut dengan nilai- nilai keyakinan Islam, yang utama berasal seluruh perjuangan pembinaan sikap keagamaan wajib ditanamkan pada segala susunan

\footnotetext{
${ }^{1}$ Farida Asyari, 'TANTANGAN GURU PAI MEMASUKI ERA REVOLUSI INDUSTRI 4.0 DALAM MENINGKATKAN AKHLAQ SISWA DI SMK PANCASILA KUBU RAYA KALIMANTAN BARAT', Muslim Heritage, $4.2 \quad$ (2019) $<$ https://doi.org/10.21154/muslimheritage.v4i2.1779>.
} 
serta strata warga, mulai tingkatan atas hingga ke susunan dasar. serta para susunan atas seperti itu yang pertama- tama wajib membagikan teladan yang baik kepada warga. Perihal ini bisa jadi merupakan tranformasi perilaku keagamaan berasal suatu norma agama yang terbawa- bawa dari Kerutinan baru pada masa media baru ialah pada masa 4. 0 dikala ini.

Media menyampaikan transformasi suatu perilaku warga dalam menyikapi suatu nilai kepercayaan. Pergeseran ini ialah bentuk dari transformasi. Transformasi maksudnya suatu proses pergantian bertahap sampai di sesi akhir, pergantian yang dicoba memakai metode berikan reaksi terhadap akibat faktor eksternal dan internal yang hendak memusatkan pergantian dari wujud yang sudah diketahui tadinya lewat proses menggandakan secara berulang-ulang ataupun melipat gandakan.

Maksud transformasi ini ialah masyarakat yang merespon kenyataankenyataan sikap yang disuguhkan media pada era 4.0 ini, memberikan perubahan bersikap dan berperilaku sehingga nilai agama mulai mengalami perubahan (transformasi). Hal ini menjadikan nilai keagamaan di masyarakat bergeser berasal nilai yang semestinya. Misalkan media saat ini lebih cenderung menginformasikan sesuatu yang belum seksama kebenarannya tetapi dianggap sahih di sebagian masyarakat.

Misalnya adalah konten tiktok seorang wanita yang berjilbab serta bercadar bergoyang-goyang tetapi di dalamnya menyuguhkan pesan nasehat. Ini sebenarnya telah menghambat nilai keagamaan berupa perilaku yang semestinya tidak sahih meskipun ingin menyampaikan nasehat kepercayaan. Kita juga disuguhi modelmodel yang menyedihkan, berhijab tapi menampakkan lekuk tubuh yang menonjol serta terkesan transparan. Hal ini menyampaikan cerminan yang tidak suai dengan sikap menggunakan keagamaan seseorang yang religious.

Arus globalisasi ini dengan mudah mempengaruhi masyarakat serta menyampaikan berbagai akibat. salah satu akibat tadi transformasi perilaku warga dalam beragama. Media lebih banyak menyiarkan hal-hal bernuasa kepercayaan, namun menyimpang berasal sikap yang semestinya di tampilkan. Dan hal ini menyampaikan dampak besar pada masyarakat yang menontonya seolah-olah perilaku ini benar serta menjadikan suatu budaya tren. Hal ini sudah tidak bisa terkontrol jika upaya pada bermedia tidak diperhatikan. Jika keadaan ini tidak 
segera ditangani berfokus maka akan berdampak hancurnya perilaku, moral, dan akhlak berperilaku dalam bermasyarakat. Ini merupakan bentuk transformasi perilaku beragama di zaman media baru saat ini. Mengalami fenomena tersebut, tuduhan acapkali kali ditunjukan pada global pembelajaran jadi penyebabnya. Perihal ini sanggup dipahami sebab pembelajaran terletak di barisan terdepan pada mempersiapkan sumber energi yang bermutu dan berakhlak mulia. Pada masa revolusi industri ini memiliki akibat terhadap global pembelajaran.

Banyak pergantian perilaku yang dirasakan masyarakat dengan notabene ialah generasi milenial yang sudah tidak asing lagi memakai dunia digital dan mereka telah terbiasa memakai arus kabar serta teknologi industri 4.0. Proses transformasi mengandung dimensi waktu dan perubahan sosial budaya warga yang menempati yang ada melalui proses yang panjang yang selalu terkait dengan aktivitas-kegiatan yang terjadi di waktu itu. Merupakan integrasi pendidikan Islam dalam prespektif trasnformasi menuju pendidikan Islam berkualitas memadukan sains, spiritual menggunakan pendidikan karakter sebagai ciri khas suatu bangsa mutlak diperlukan. Hal ini menerangkan bahwa terjadinya tranformasi perilaku keagamaan, nilai pendidikan agama yang saat ini tidak lagi jadi pedoman pada bertindak dan berperilaku dalam kehidupan bermasyarakat. Ini merupakan bagian berasal dampak tren di dunia industri 4.0 sebab semua akses buat menggunakan media dan info bisa terakses dengan cepat.

Namun demikian, seiring dengan kemajuan teknologi info serta digital menggunakan kulturnya yang spesial, praktek beragama pun mengalami transformasi. Media yang tadinya bisa menyampaikan imbas positif pula bisa menyampaikan akibat negative, menjadi penguatan moderasi beragama, pendidikan kepercayaan di masa transformasi perilaku keagamaan pada era 4.0 ini, perlu kita bahas bagaimana tranformasi sikap keagamaan pada era media baru 4.0? kemudian bagaimana memberikan solusi buat mengatasi transformasi perilaku beragama dalam penguatan moderasi beragama berbasis literasi pada era media baru 4.0 


\section{LANDASAN TEORI}

\section{Transformasi Perilaku Keagamaan}

Transformasi ialah pergantian yang terjalin dari kondisi yang tadinya jadi baru dan lebih baik. Dari Kamus Bahasa Indonesia transformasi maksudnya pergantian, berganti berasal kondisi yang tadinya jadi baru sama sekali ${ }^{2}$.Suatu proses pergantian secara berangsur- angsur yang dicoba memakai metode berikan reaksi terhadap faktor eksternal dan internal yang hendak memusatkan pergantian dari wujud yang telah diketahui tadinya lewat proses menggandakan secara berulang- ulang ataupun melipatgandakan. Handayani mendeskripsikan transformasi jadi pergantian wujud, rupa, watak dan sebagainya. Pergantian yang diartikan merujuk di sosio- kultural. Sosio- kutural yang hendak dibahas lebih di aspek perilaku keagamaan. Selaku dampaknya transformasi yang diartikan ialah perpindahan sikap keagamaan rakyat, berasal perilaku sinkretis mengarah sikap murni. ${ }^{3}$ Perubahan yang terjadi berasal keadaan yang sebelumnya menjadi baru sama sekali. Perubahan tadi dikarenakan kondisi warga yang berubah.

Perubahan dapat disebabkan oleh faktor internal seperti sikap warga dan faktor eksternal seperti lingkungan. Orang-orang yang telah mengalami cara berpikir yang berbeda tidak menyinkronkan pandangan mereka. Misalnya dari segi makna, cara orang memaknai peristiwa yang ada dalam kehidupan, meskipun peristiwa itu terjadi berulang kali, mengubah makna sebelumnya. Masyarakat Indonesia yang umumnya didominasi oleh agama Islam memiliki berbagai bentuk perilaku keagamaan secara umum. Berbagai bentuk perilaku keagamaan memecah belah masyarakat berdasarkan praktik keagamaan. Cendekiawan Islam Indonesia menyebut mereka bagian dari gerakan Puritan, ada yang menyebut mereka Islam Reformed, Islam modern, dan ada pula yang menyebut mereka Islam Reformed. Transformasi di satu sisi berarti proses perubahan atau pembaruan struktur sosial, dan di sisi lain proses perubahan nilai. Fokus awal perubahan tematik adalah perubahan di bidang sikap keagamaan. Konversi juga membutuhkan proses yang

2 Daryanto, Kamus Besar Bahasa Indonesia (Surabaya: Apollo, 1997).

3 Baiq Lily Handayani, 'TRANSFORMASI PERILAKU KEAGAMAAN (Analisis Terhadap Upaya Purifikasi Akidah Melalui Ruqyah Syar'iyah Pada Komunitas Muslim Jember)', Sosiologi Islam, 1.2 (2011).. 2011. 
lengkap. Zaeny mendeskripsikan suatu proses transformasi menggunakan tiga unsur. Unsur-unsur tersebut mencakup:

a) Perbedaan merupakan aspek yang sangat penting pada dalam proses transformasi.

b) Konsep karakteristik atau identitas yang artinya acuan pada dalam suatu proses transformatif jikalau dikatakan sesuatu itu tidak sinkron, maka haruslah kentara perbedaan berasal hal apa, karakteristik sosial, ekonomi atau ciri penerapan dari sesuatu.

c) Proses transformasi selalu bersifat historis yang terikat pada sekalian wakil yang berbeda. Oleh karena itu transformasi selalu menyangkut perubahan rakyat dari suatu warga lebih sederhana ke warga yang lebih terkini. ${ }^{4}$

Perubahan tersebut terjadi karena adanya perubahan situasi warga, yang dapat disebabkan oleh faktor internal seperti pikiran masyarakat atau faktor eksternal seperti lingkungan. Akibatnya, warga yang mengalami disonant thinking memiliki pandangan yang berbeda. Era baru media 4.0 ini, warga mengalami pergeseran ihwal cara pandang pada berperilaku. Menilai suatu kepercayaan berasal media. Pemberitaan yang bisa diakses pada berbagai media, membuahkan transformasi pola pikir yang membawa efek ke perilaku warga.

Dalam beragama, kepercayaan masyarakat disuguhi menggunakan kontenkonten Islami, tapi cara penyampaian yang tidak sesuai syariat Islam. Hal ini sebenarnya tidak sahih, namun warga yang menggangap pemberitaan setiap media ialah sahih, maka mayarakat telah punya cara pandang sendiri pada berperilaku dengan agamanya. menggunakan demikian transformasi adalah perubahan yang terjadi dari keadaan yang sebelumnya sebagai baru sama sekali dikarenakan syarat masyarakat mengalami pergeseran tentang cara pandang pada berperilaku.

\section{Perilaku Keagamaan}

Dalam Kamus Besar Bahasa Indonesia, perilaku diartikan sebagai reaksi/reaksi individu terhadap suatu rangsangan/lingkungan. ${ }^{5}$ Tingkah laku adalah

${ }^{4}$ M Darojat Ariyanto, 'Terapi Ruqyah Terhadap Penyakit Fisik, Jiwa Dan Gangguan Jin', Suhuf, 19.1 (2007).

${ }^{5}$ Daryanto. 
tingkah laku yang dapat diamati dan dipelajari. Sebelum membentuk pola sikap, seseorang memiliki bentuk sikap yang dihasilkan dari stimulus eksternal, dan kemudian sikap itu membentuk sikap baru. ${ }^{6}$ Menurut Sarlito Wirawan, perilaku adalah perilaku manusia yang jarang terjadi (muncul dan menghilang pada saat-saat penting), tetapi ada kesinambungan antara satu perilaku dengan perilaku lainnya. Sedangkan pendapat Ghazalie yang dikutip oleh Hasan Langgrun tentang definisi perilaku berarti bahwa:

a) Tingkah laku memiliki pendorong (motivasi), penggerak, arah dan tujuan, serta bersifat objektif.

b) Motivasi berasal dari dalam diri sendiri, namun dirangsang menggunakan stimulus dari luar, atau yang berhubungan menggunakan kebutuhan jasmani serta kesamaan atau kecenderungan alamiah, mirip rasa lapar, cinta, dan takut pada Allah SWT.

c) Menghadapi motivasi-motivasi diri mendapati dirinya terdorong dalam melakukan sesuatu.

d) Tingkah laku mencakup rasa kebutuhan dengan perasaan eksklusif serta kesadaran logika terhadap suasana tersebut.

e) Kehidupan psikologis adalah suatu perbuatan bergerak maju dimana berlaku hubungan antara tujuan atau motivasi serta tingkah laku.

f) Tingkah laris itu bersifat individual yang tidak selaras menurut perbedaan faktor-faktor keturunan dan perolehan/proses belajar

g) Sepertinya tingkah laku manusia berdasarkan A-Ghazali terdapat dua tingkatan. Pertama, manusia berdekatan menggunakan semua makhluk hidup, sedangkan yang ke dua, dia mencapai idealnya serta mendekatkan pada makna-makna ketuhanan serta tingkah laku malaikat. $^{7}$

Sikap adalah suatu kegiatan yang terdiri dari diri kita sendiri karena adanya reaksi dari luar. Akibatnya, perilaku positif terbentuk dan sebaliknya. Perubahan perilaku dipengaruhi oleh perubahan perilaku terhadap sesuatu. Dengan kata lain, untuk mengubah arah atau mengarahkan tindakan seseorang, pertama-tama kita

\footnotetext{
2005.

${ }^{6}$ Sarlito Wirawan Sarwono, 'Pengantar Psikologi Umum', Yogyakarta: Rajawali Pers, ${ }^{7}$ Ibid, 98.
} 
harus mengubah sikap kita. Mencermati perilaku manusia dan lapisan-lapisan perilaku, kepercayaan berarti mereka yang mencapai tingkat kedua, ideal, dan mendekati makna ketuhanan dan perilaku malaikat. Agama sebagai sistem simbol yang kompleks yang mengekspresikan dan mendukung emosi dan nilai-nilai masyarakat dan memungkinkan terwujudnya kehidupan sosial yang mendukungnya. Dari sudut pandang fungsionalis, iman (agama atau agama) adalah sistem kompleks kepercayaan, keyakinan, tindakan, dan ritual yang menggunakan kehadiran Tuhan untuk menghubungkan individu. ${ }^{8}$

Menurut Durkheim, kepercayaan harus memiliki fungsi, karena kepercayaan tidak baik, tetapi itu adalah penutup sosial yang dapat diidentifikasi dan kepentingan sosial. ${ }^{9}$ Dalam agama, ada keyakinan pada orang-orang yang bergantung pada kesejahteraan mereka di seluruh dunia dan di bawah keberadaan hubungan yang baik dengan kekuasaan. Hubungan manusia dengan para dewa adalah bentuk kegiatan keagamaan Saint dan legalitas kepercayaan yang dapat ditelusuri dalam segala usia, wilayah, budaya dan peradaban menunjukkan bahwa orang memiliki perjanjian alami untuk percaya pada kekuasaan. Dalam Al-Qur'an, kecenderungan alami dikonfirmasi bahwa itu Fitrah. Karena sifat ini, pada dasarnya orang membutuhkan alat untuk respons yang lebih emosional. Bentuk-bentuk reaksi terinspirasi, akan menciptakan nilai sebagai dasar untuk kehidupan manusia yang beragama. ${ }^{10}$

Iman berakar pada wahyu ilahi. Oleh karena itu, keberagamaan pun merupakan sikap memiliki sumber wahyu ilahi yang bersifat pribadi atau nonpribadi. Ada beberapa aspek dalam agama. Dimensi tersebut meliputi dimensi pertama adalah aspek kognitif agama, dua terakhir adalah aspek perilaku agama, dan dimensi terakhir adalah aspek emosional agama. Bagi umat Islam, agama harus dilihat sejauh jumlah keyakinan, pengetahuan, konsistensi dalam penerapan ibadah ritual keagamaan, rasa syukur atas keyakinan Islam, dan dampak keyakinan tercermin dalam tindakan Anda. Dalam Islam, jika Anda bisa merasakan betapa

\footnotetext{
${ }^{8}$ Achmad Fedyani Saifudin, Antropologi Kontemporer: Suatu Pengantar Kritis Mengenai Paradigma (Jakarta: Kencana, 2006).

9 JP Chaplin, Kamus Lengkap Psikologi: Terj. Kartini Kartono (Jakarta: Raja Grafindo Persada, 2004).

${ }^{10}$ Syamsuddin Abdullah, Agama Dan Masyarakat, Pendekatan Sosiologi Agama (Ciputat: Logos Wacana Ilmu, 1997).
} 
dalam penghargaan Anda terhadap agama Anda, agama Anda akan lebih luas dan lebih dalam. Berdasarkan uraian di atas, dimensi agama dalam Islam terdiri dari lima dimensi: Aqidah (iman atau ideologi), ibadah (ritual), amal (amalan), dan Isan. (Terima kasih, situasi di mana Anda merasa terbiasa menggunakan Allah), dan dimensi ilmu (pengetahuan).

Nilai harus dilembagakan karena kehidupan manusia tidak memiliki tanggal asal usul nilai. Pengaturan nilai terbaik berarti melalui upaya pendidikan. Allah menghendaki agar orang-orang beriman (Islam) secara keseluruhan rukun dan terus menerus beragama, serta sebagai satu aspek atau dimensi yang eksklusif. Oleh karena itu, seluruh umat Islam harus berlandaskan pada nilai-nilai dan tata cara ajaran Islam, baik dalam berpikir, dalam bertindak maupun dalam bertindak. Dalam agama, ada kepercayaan manusia bahwa kesejahteraan Anda di dunia dan di akhirat tergantung pada hubungan yang baik dengan kekuatan-kekuatan ini. Bentuk-bentuk respons ini pada gilirannya menciptakan nilai yang menjadi dasar cara hidup religius masyarakat.

Oleh karena itu, agama yang baik akan memberikan setiap individu jiwa yang sehat dan membentuk kepribadian yang kuat dan seimbang. Ada beberapa aspek dalam agama. Dalam dimensi tersebut, dimensi pertama adalah aspek kognitif agama, dua terakhir asal-usul adalah aspek perilaku keragaman, dan dimensi terakhir adalah aspek emosional agama. Glock dan R Stark, sebagaimana dikutip CY Djamaluddin dalam bukunya American Piety: The Nature of Religion Commitment, memiliki lima aspek keimanan manusia: aspek idealis, aspek kultus, dan aspek praktik keagamaan (ritual), Dimensi syukur (pengalaman), dimensi amalan (akibat) dan dimensi ilmu agama (intelektual)

\section{Era Media Baru 4.0}

Revolusi Industri 4.0 telah berdampak besar bagi kehidupan generasi milenial dan juga mempengaruhi fungsi hubungan sosial dalam kehidupan nyata, banyak generasi milenial berjuang untuk mempertahankan eksistensinya di media sosial. Revolusi industri 4.0 merubah perkembangan manusia sebagaimana mestinya, pola interaksi yang berubah menjadi lebih simple berkat bantuan teknologi komunikasi dan informasi, tetapi tidak semua generasi yang mampu menyesuaikan diri termasuk generasi milenial, ada nilai positif dan negatif dalam 
perkembangan teknologi, perubahan cara pikir generasi milenial melihat lingkungan sekitar seperti sistem kepercayaan (belifs), nilai (values), dan sikap (attitudes). Dalam hal kepercayaan (beliefs) media sosial mampu mengubah perilaku masyarakat sesuai dengan iman dan kepercayaan mereka. Ini terlihat ketika mereka lebih mengedepankan teknologi ketimbang yang lain. Secara keberfungsian sosial generasi milenial memiliki kekuatan yang tidak dipunya oleh generasi sebelumnya, yaitu masalah kreatifitas, jaringan media sosial yang luas serta kepercayaan diri terhadap hasil karya mereka, kelemahan mereka terlihat dari krisis kepercayaan diri ketika hasil yang kemudian bergeser oleh kehadirannya. Sedangkan dalam sikap (beliefs), media sosial merubah cara masyarakat berkomunikasi. ${ }^{11}$

Manusia yang beriman adalah manusia yang mampu secara optimal menghayati dan mengamalkan ajaran agamanya dalam kehidupan sehari-hari. Penampilan sikap pengabdiannya terhadap Allah SWT. dan kepada lingkungannya baik sesama manusia maupun terhadap alam sekitarnya dalam penghayatan dan pengamalan ajaran agama diperlukan pembinaan sedini mungkin melalui proses pendidikan yang juga diperankan oleh pendidikan agama. Dalam hubungan ini pendidikan agama berfungsi sebagai usaha membina manusia berakhlak tinggi Revolusi Indsutri 4.0 tidak mungkin hanya dihadapi dengan pengembangan teknologi tanpa melibatkan dinamika sosial di dalamnya. Selain menyiapkan daya saing yang unggul, perlu dibangun kesadaran dan kedewasaan masyarakat dalam menyikapi perkembangan dunia saat ini, terutama di zaman post truth ketika informasi yang mengalir deras tanpa kejelasan kebenarannya. Perlu dirumuskan strategi kebijakan nasional melalui kesadaran dan kedewasaan berpikir. Ini membawa arah transformasi perilaku beragama di era media baru. ${ }^{12}$

Perkembangan dari teknologi akan memberikan kebermanfaatan kepada setiap generasi, tetapi hanya generasi yang mampu beradaptasilah yang akan bisa mengendalikan teknologi, termasuk generasi milenial. Generasi milenial lahir dalam keadaan semua serba teknologi secara logika mereka akan cepat beradaptasi

11 R Willya Achmad W and others, 'POTRET GENERASI MILENIAL PADA ERA REVOLUSI INDUSTRI 4.0', Focus: Jurnal Pekerjaan Sosial, 2.2 (2020) $<$ https://doi.org/10.24198/focus.v2i2.26241>.

${ }^{12}$ Banu Prasetyo and Danumi Trisyanti, 'Strategi Pembangunan Nasional Menghadapi Revolusi Industri 4.0" REVOLUSI INDUSTRI 4.0’, Institut Teknologi Sepuluh November, 2019. 
sehingga teknologi akan membantu generasi milenial dalam menjalankan keberfungsiannya tetapi seiring berjalannya waktu terdapat miss persepsi terhadap penggunaan teknologi, maka diperlukan sebuah pemahaman masalah atau assessment untuk melihat dan mengetahui gambaran kondisi permasalahan yang dialami generasi milenial pada era revolusi industri 4.0. Proses interaksi sosial masyarakat yang berkesinambungan mengikuti dan menjalankan norma-norma tertentu termasuk norma-norma agama, pergaulan sosial atau interaksi sosial berjalan lancar, yang terjadi antara individu dengan individu lainnya, juga dengan kelompok sosial adalah dengan mempedomani norma yang ada, selain norma agama juga ada norma sosial. Hal ini adalah bentuk transformasi perilaku beragama dalam masyarakat di era media baru.

Perubahan cara pandang membentuk atau mengelola industri ini pula, juga berdampak pada cara orang memahami agama, mengekspresikan, serta mengkomunikasikan kepada orang lain. Di era sebelumnya, orang memahami agama, bisa saja dengan model sangat sederhana, yakni; melihat apa yang mengejawantah di sekitar mereka. Memandang apa yang ditauladankan oleh tokoh agama, ataupun mendatangi lembaga-lembaga keagamaan untuk belajar agama. Namun hari ini, di era yang sudah terdigitalisasi, sebagaimana karateristik di atas, agama sudah masuk ke ruang publik tanpa batasan apapun. Agama hadir pada diskursus yang tergitalisasi. Agama hadir sebagai pilihan yang dikomunikasikan dengan cara-cara yang lebih mudah dibandingkan sebelumnya. Agama pun 'bisa menjadi alat' untuk menghasilkan keuntungan ekonomi, melalui pemanfataan pendekatan karakter masyarakat di era revolusi industri 4.0. seperti contoh media yang digunakan masyarakat berupa aplikasi tiktok untuk memberikan pesan nasihat, namun banyak terdapat dampak perilaku keagamaan dari pengguna tik tok ini tidak lagi pada tatanan keagamaannya, malahan merusak dari perilaku keagamaan itu sendiri. Pemanfaatan industry media sosial ini, menjadikan karakter orang lain dalam menilai perilaku keagamaanitu sendiri baik dari segi agama namun cara penyampaiannya yang kurang tepat, sehingga perilaku yang di tampilkan merusak kareakter agama itu sendiri.

Dasar perubahan ini sebenarnya adalah pemenuhan hasrat keinginan pemenuhan kebutuhan manusia secara cepat dan berkualitas. Revolusi Industri 
telah mengubah cara kerja manusia dari penggunaan manual menjadi otomatisasi atau digitalisasi ${ }^{13}$. Inovasi menjadi kunci eksistensi dari perubahan itu sendiri. Revolusi industri ini pun sedang berjalan dari masa ke masa. Dekade terakhir ini sudah dapat disebut memasuki fase ke empat 4.0. Perubahan fase ke fase memberi perbedaan artikulatif pada sisi kegunaaannya.

\section{METODOLOGI PENELITIAN}

Penelitian ini menggunakan pendekatan penelitian kualitatif dan jenis penelitiannya yaitu deskripsi analisis berupa data tertulis dengan mendeskripsikan kembali data yang terkumpul dari objek penelitian. ${ }^{14}$ Sedangkan untuk memperoleh data yang berkenaan dengan judul penelitian penulis menggunakan jenis metode pengumpulan data kepustakaan (Library Research). Metode yang penulis gunakan yaitu kajian dengan menelaah dan menelusuri literatur yang berkenaan dengan masalah yang di teliti baik berupa buku-buku, artikel-artikel, website dan tulisan lain yang mengandung informasi dan data-data yang berkaitan dengan judul. Penelitian kualitatif ini digunakan karena beberapa pertimbangan. Pertama, penelitian kualitatif lebih mudah apabila berhadapan dengan kenyataan ganda; kedua, penelitian ini menyajikan secara langsung hakikat hubungan antara penelitian dan responden dan ketiga, penelitian ini lebih peka dan lebih dapat menyesuaikan diri dengan banyak penajaman pengaruh bersama dan terhadap polapola nilai yang dihadapi. ${ }^{15}$

Metode pengumpulan data merupakan langkah yang paling strategis dalam penelitian, karena tujuan dari penelitian itu sendiri adalah untuk mendapatkan data. Proses pengumpulan data penelitian juga dipengaruhi dari jenis sumber data. Dikarenakan jenis sumber data dalam penelitian ini adalah orang (person) dan kertas atau tulisan (paper) maka untuk memperoleh dan mengumpulkan data digunakan metode pengumpulan data yang digunakan adalah:

${ }^{13}$ Evguenia Bessonova and Ksenia Gonchar, 'How the Innovation-Competition Link Is Shaped by Technology Distance in a High-Barrier Catch-up Economy’, Technovation, 86-87 (2019) $<$ https://doi.org/10.1016/j.technovation.2019.01.002>.

${ }^{14}$ Lexy J. Moleong, Metode Penelitian Kualitatif (Bandung: Remaja Rosdakarya, 2007).

15 Ibid, 5 . 
a. Metode Observasi

Metode observasi sering juga disebut metode pengamatan yaitu alat pengumpulan data yang dilakukan dengan cara mengamati dan mencatat secara sistematik gejala-gejala yang diselidiki. ${ }^{16}$ Dalam hal ini peneliti sendiri yang akan menjadi pengamat dengan melakukan pengamatan langsung.

b. Metode Interview (Wawancara)

Metode Interview atau wawancara yaitu percakapan antara seseorang yang berharap mendapatkan informasi dari informan; seseorang yang diasumsikan mempunyai informasi penting terhadap suatu objek. Percakapan itu dilakukan oleh kedua belah pihak, yaitu pewawancara (interviewer) yang mengajukan pertanyaan dan terwawancara (interviewee) yang memberikan jawaban atas pertanyaan yang diajukan. Menurut peneliti Interview atau wawancara adalah proses komunikasi dua arah berbentuk tanya jawab antara dua orang tau lebih baik secara langsung (bertatap muka) maupun tidak langsung dalam rangka menggali informasi dari pihak yang diwawancarai.

Dalam proses ini, hasil wawancara ditentukan oleh beberapa faktor yang berinteraksi dan mempengaruhi arus informasi. Faktor-faktor tersebut ialah: pewawancara, responden, topik penelitian yang tertuang dalam daftar pertanyaan, dan situasi wawancara ${ }^{17}$. Oleh karena itu dalam melakukan wawancara, peneliti telah menyiapkan instrument penelitian berupa pertanyaan-pertanyaan tertulis.

c. Metode Dokumentasi

Metode dokumenter ialah pengumpulan data dari data-data yang telah didokumentasikan dalam berbagai bentuk. ${ }^{18}$ Metode ini digunakan untuk memperoleh data tentang Transformasi Perilaku Beragama Di Era Media Baru 4.0.

\section{HASIL DAN PEMBAHASAN}

\section{Tranformasi Perilaku Keagamaan Di Era Media Baru 4.0}

Logos "revolusi industri 4.0" hadir sebagai bentuk dari penamaan era dan zaman yang hari ini dihadapi oleh masyarakat dunia. Penamaan ini tidak jauh

\footnotetext{
${ }^{16}$ Cholid Narkubo dan Abu Achmadi, Metodologi Penelitian (Jakarta: Bumi Aksara, 2009).

${ }^{17}$ Masri Singarimbun, Metodelogi Penelitian Survai (Jakarta: LP3ES, 1989).

${ }^{18}$ Burhan Bungin, Metode Penelitian Kualitatif(Jakarta: Kencana, 2006).
} 
berbeda dengan kata klasik, modern, dan kontemporer, hanya berbeda dari sumber (arbiter) penamaannya. Kata 'revolusi industri 4.0' berasal dari narasi pemanfaatan ilmu pengetahuan, teknologi informasi, dan perubahan mindset pemahaman akan kondisi ekonomi, bisnis, dan manajerialisme di dalamnya ${ }^{19}$. Robert Philips menyederhanakan kondisi ini dengan menganggap bahwa revolusi industri 4.0 bermakna sebuah kondisi dimana manusia terinteraksi dan terintegrasi pada model kehidupan yang serba terdigitalisasi, terbantukan oleh teknologi dan mesin, sekaligus, kekuatan ilmu pengetahuan dalam mengatur pola hidup masyarakat secara efektif dan efesien. ${ }^{20}$

Perubahan cara pandang membangun atau mengelola industri ini pula, juga berdampak pada cara orang memahami agama, mengekspresikan, serta mengkomunikasikan kepada orang lain. Di era sebelumnya, orang memahami agama, bisa saja dengan model sangat sederhana, yakni; melihat apa yang mengejawantah di sekitar mereka. Memandang apa yang ditauladankan oleh tokoh agama, ataupun mendatangi lembaga-lembaga keagamaan untuk belajar agama. Namun hari ini, di era yang sudah terdigitalisasi, sebagaimana karateristik di atas, agama sudah masuk ke ruang publik tanpa batasan apapun.

Agama hadir pada diskursus yang tergitalisasi. Agama hadir sebagai pilihan yang dikomunikasikan dengan cara-cara yang lebih mudah dibandingkan sebelumnya. Agama pun 'bisa menjadi alat' untuk menghasilkan keuntungan ekonomi, melalui pemanfataan pendekatan karakter masyarakat di era revolusi industri 4.0. seperti contoh media yang digunakan masyarakat berupa aplikasi tiktok untuk memberikan pesan nasihat, namun banyak terdapat dampak perilaku keagamaan dari pengguna tik tok ini tidak lagi pada tatanan keagamaannya, malahan merusak dari perilaku keagamaan itu sendiri. Pemanfaatan industry media sosial ini, menjadikan karakter orang lain dalam menilai perilaku keagamaan itu sendiri baik dari segi agama namun cara penyampaiannya yang kurang tepat, sehingga perilaku yang di tampilkan merusak karakter agama itu sendiri.

19 Roland Berger, 'Industry 4.0, The New Industrial Revolution: How Eu Rope Will Succeed', Rolandberger.Com.

20 Jacobus Oosthuizen, 'The Determinant of Fourth Industrial Revolution Leadership Dexterity; a Poposed Framework for 4IR-Inteligence and Subsequest 4IR Leadership Development', in Proceeding of International Conference of Resources Management (Milpark Buiness School), p. 32. 
Revolusi Industri 4.0 secara fundamental mengakibatkan berubahnya cara manusia berpikir, hidup, dan berhubungan satu dengan yang lain. Era ini akan mendisrupsi berbagai aktivitas manusia dalam berbagai interaksi sosialnya. Perilaku dan kebiasaan pada generasi milenial yang berusia 18-40 tahun itu mempunyai tingkat antusiasme terhadap penggunaan teknologi cukup tinggi, tetapi mempengaruhi terhadap sikap dan perilakunya. Industri 4.0 banyak membawa perubahan dalam kehidupan manusia. Industri 4.0 secara fundamental telah mengubah cara beraktivitas manusia dan memberikan pengaruh yang besar terhadap transformasi perilaku beragama masyarakat. Masyarakat terkontaminasi dengan suguhan-suguhan media yang tidak punya batas waktu dan ruang. Media hampir $90 \%$ menjadi prioritas dalam bersosial. Dijadikan ajang bisnis. Dengan konten-konten Islami, para media membuat suatu kelompok agamais dalam kegiatan bersosial.

Dasar perubahan ini sebenarnya adalah keinginan dalam memenuhi kebutuhan manusia secara cepat dan berkualitas. Revolusi Industri telah mengubah cara kerja manusia dari penggunaan manual menjadi otomatisasi atau digitalisasi. ${ }^{21}$ Inovasi menjadi kunci eksistensi dari perubahan itu sendiri. Revolusi industri ini pun sedang berjalan dari masa ke masa. Dekade terakhir ini sudah dapat disebut memasuki fase ke empat (4.0). Perubahan fase ke fase memberi perbedaan artikulatif pada sisi kegunaaannya. Salah satunya dalam memberikan pencitraan perilaku keagamaan. Sekarang lebih banyak masyarakat menyiarkan agama mengunakan media. Ada beberapa aplikasi yang dapat digunakan sebagai alat komunikasi.

Tiktok salah satu aplikasi yang memberikan ruang peraga dalam menyiarkan pesan. Pesan atau perilaku yang ditimbulkan dalam menggunakan aplikasi ini berfariasi. Konten-konten yang di siarkan banyak mengacu pada perilaku yang terkadang nilai positifnya cenderung mengarahkan ke negative. Misalnya seperti seseorang pengguna media aplikasi tiktok ini menggunakan jilbab, namun begoyang-goyang dengan diiringi musik dan berperilaku selayaknya tidak etis dengan konten yang berisikan perintah yang Islami. Isi pesan yang di sampaikan menunjukan ingin berperilaku keagamaan, namun akhlak tidak patut

\footnotetext{
${ }^{21}$ Bessonova and Gonchar.
} 
dan tidak suai dengan isi konten. Hal ini merupakan dampak transformasi perilaku keagamaan di era media baru 4.0. Masyarakat merespon media dengan asumsiasumsi yang timbul dimasyarakat, bahwa dengan berperilaku ke'agamais'an, media akan memberi ruang keter'eksis'an seseorang di era media baru saat ini. Transformasi ini membawa dampak setiap pelaku media baru, terjadi perubahan yang drastis dalam berperilaku.

\section{Upaya Mengatasi Transformasi Perilaku Keagamaan Di Era Media Baru}

Moderasi dalam pandangan Al-qur'an menjadi inti dari sebuah tatanan masyarakat yang ideal (Khaira Ummah). Konsep Al-qur’an menjadi tawaran yang kuat di tengah pergulatan wacana keilmuan sepanjang sejarah manusia tentang masyarakat. Lebih baik kita kembali ke konsep Al-qur'an karena inilah pegangan dan pedoman kita dalam memahami Islam. Dalam era revolusi industri ini memiliki pengaruh terhadap dunia pendidikan. Transformasi perilkaku keagamaan yang di pengaruhi media masa di era industi 4.0 ini memberikan dampak kepada tatanan sosial di masyarakat. Banyak perubahan sikap yang dialami masyarakat dalam berperilaku beragama. dengan notabene adalah generasi milenial yang sudah tidak asing lagi dengan dunia digital dan mereka telah terbiasa dengan arus informasi dan teknologi industri 4.0 .

Sikap-sikap yang muncul antara lain kecanduan gadget, cyber bullying, atau bahkan turunnya moral atau akhlak. Ini merupakan transformasi perilaku keagamaan di era media baru. Sehingga sudah sepatutnya masyarakat yang mengalami transformasi perilaku keagamaan memikirkan upaya yang tepat dalam menghadapi perubahan-perubahan perilaku masyarakat itu sendiri di era 4.0 ini. Terwujudnya kehidupan masyarakat yang berpegang teguh kepada akhlak tidak lain kecuali dengan pendidikan khususnya pendidikan agama Islam akan berdampak pada hancurnya sikap, moral, dan akhlak serta perilaku yang menyimpang dalam beragama. Dalam hubungan ini pendidikan agama berfungsi sebagai usaha membina manusia berakhlak tinggi. Disinilah letak fungsi pendidikan agama dalam menentukan kemajuan dan runtuhnya suatu bangsa. Pendidikan agama berperan dalam memberikan pencerahan pada era zaman industry 4.0 bahwa yang benar tetaplah sesuai hadist dan alquran. 


\section{KESIMPULAN}

Islam mengajarkan bahwa setiap ciptaan Allah SWT memiliki segudang manfaat. Dia tidak menciptakan makhluk dengan sia-sia dan tanpa tujuan. Dia telah memperhitungkan segala ciptaannya dengan sempurna. Dengan kata lain, Islam menilai bahwa masalah atau cobaan adalah suatu pelajaran yang bernilai positif karena dari setiap permasalahan merupakan gudang hikmah yang sangat berharga. Banyak perubahan sikap yang dialami masyarakat dalam berperilaku beragama. dengan notabene adalah generasi milenial yang sudah tidak asing lagi dengan dunia digital dan mereka telah terbiasa dengan arus informasi dan teknologi industri 4.0. Perubahan cara pandang membangun atau mengelola industri ini pula juga berdampak pada cara orang memahami agama, mengekspresikan, serta mengkomunikasikan kepada orang lain. Masyarakat yang merespon fenomenafenomena perilaku yang disuguhkan media di era 4.0 ini, memberikan perubahan bersikap dan berperilaku dalam penggunaannya sehingga nilai agama mulai mengalami perubahan (transpormasi). Upaya sudah sepatutnya di lakukan sebagai penguatan pendidikan keagamaan dikalangan masyarakat dalam menghadapi perubahan-perubahan perilaku masyarakat di era 4.0 ini. Islam memikirkan upaya yang tepat dalam menghadapi perubahan-perubahan perilaku tersebut.

Moderasi dalam pandangan Al-qur'an menjadi inti dari sebuah tatanan masyarakat yang ideal (Khaira Ummah). Konsep Al-qur`an menjadi tawaran yang kuat di tengah pergulatan wacana keilmuan sepanjang sejarah manusia tentang masyarakat. Lebih baik kita kembali ke konsep Al-qur'an karena inilah pegangan dan pedoman kita dalam memahami Islam. Dalam era revolusi industri ini memiliki pengaruh terhadap dunia pendidikan. Dalam hubungan ini pendidikan agama berfungsi sebagai usaha membina manusia secara religious dan kaffah yang mampu menyesuaikan diri dalam menghadapi Era 4.0 manusia dituntut kreatif menyikapi media sebagai alat komunikasi di era industri yang serba cepat, tepat, efektif dan efisien. Disinilah letak fungsi pendidikan agama dalam menentukan kemajuan dan runtuhnya suatu bangsa. 


\section{DAFTAR PUSTAKA}

Abdullah, Syamsuddin, Agama Dan Masyarakat, Pendekatan Sosiologi Agama (Ciputat: Logos Wacana Ilmu, 1997)

Achmadi, Cholid Narkubo dan Abu, Metodologi Penelitian (Jakarta: Bumi Aksara, 2009)

Ariyanto, M Darojat, 'Terapi Ruqyah Terhadap Penyakit Fisik, Jiwa Dan Gangguan Jin', Suhuf, 19.1 (2007)

Asyari, Farida, 'TANTANGAN GURU PAI MEMASUKI ERA REVOLUSI INDUSTRI 4.0 DALAM MENINGKATKAN AKHLAQ SISWA DI SMK PANCASILA KUBU RAYA KALIMANTAN BARAT', Muslim Heritage, $4.2(2019)<$ https://doi.org/10.21154/muslimheritage.v4i2.1779>

Berger, Roland, 'Industry 4.0, The New Industrial Revolution: How Eu Rope Will Succeed', Rolandberger.Com

Bessonova, Evguenia, and Ksenia Gonchar, 'How the Innovation-Competition Link Is Shaped by Technology Distance in a High-Barrier Catch-up Economy', Technovation, 86-87

$<$ https://doi.org/10.1016/j.technovation.2019.01.002>

(2019)

Bungin, Burhan, Metode Penelitian Kualitatif(Jakarta: Kencana, 2006)

Chaplin, JP, Kamus Lengkap Psikologi: Terj. Kartini Kartono (Jakarta: Raja Grafindo Persada, 2004)

Fedyani Saifudin, Achmad. Antropologi Kontemporer: Suatu Pengantar Kritis Mengenai Paradigma (Jakarta: Kencana, 2006)

Handayani, Baiq Lily, 'TRANSFORMASI PERILAKU KEAGAMAAN (Analisis Terhadap Upaya Purifikasi Akidah Melalui Ruqyah Syar'iyah Pada Komunitas Muslim Jember)', Sosiologi Islam, 1.2 (2011)

Moleong, Lexy J., Metode Penelitian Kualitatif (Bandung: Remaja Rosdakarya, 2007)

Oosthuizen, Jacobus, 'The Determinant of Fourth Industrial Revolution Leadership Dexterity; a Poposed Framework for 4IR-Inteligence and Subsequest 4IR Leadership Development', in Proceeding of International Conference of Resources Management (Milpark Buiness School), p. 32

Prasetyo, Banu, and Danumi Trisyanti, 'Strategi Pembangunan Nasional Menghadapi Revolusi Industri 4.0" REVOLUSI INDUSTRI 4.0', Institut Teknologi Sepuluh November, 2019

Sarwono, Sarlito Wirawan, 'Pengantar Psikologi Umum', Yogyakarta: Rajawali Pers, 2005

Singarimbun, Masri, Metodelogi Penelitian Survai (Jakarta: LP3ES, 1989)

W, R Willya Achmad, Marcelino Vincentius Poluakan, Didin Dikayuana, Herry Wibowo, and Santoso Tri Raharjo, 'POTRET GENERASI MILENIAL PADA ERA REVOLUSI INDUSTRI 4.0', Focus : Jurnal Pekerjaan Sosial, $2.2(2020)<$ https://doi.org/10.24198/focus.v2i2.26241> 